\title{
Attenuation properties of common 3D printed FFF plastics for mammographic applications
}

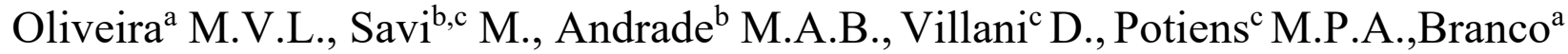 \\ H.S., Ubeda ${ }^{\mathrm{d}}$ C., Mdletshe ${ }^{\mathrm{e}} \mathrm{S}$. \\ ${ }^{a}$ Department of Technology Health and Biology, Federal Institute of Bahia, Salvador (BA), Brazil, 40301-015 \\ marcusradiology@gmail \\ ${ }^{b}$ Department of Health and Services - Federal Institute of Education, Science and Technology of Santa Catarina - \\ IFSC, Santa Catarina (SC), Brazil \\ ${ }^{\mathrm{c}}$ Radiation Metrology Center - Instituto de Pesquisas Energéticas e Nucleares - IPEN/CNEN-USP. Avenida Prof. \\ Lineu Prestes, 2242 - Cidade Universitária. São Paulo \\ ${ }^{d}$ Medical Technology Department, Health Sciences Faculty, Tarapaca University, Arica, Chile \\ ${ }^{e}$ Faculty of Medical and Health Sciences, Department of Anatomy and Medical Imaging, The University of Auckland, \\ Auckland, New Zealand
}

\section{ABSTRACT}

The aim of this study was to evaluate the feasibility of using acrylonitrile butadiene styrene (ABS) and polylactic acid (PLA) 3D printing filaments as materials for mammography phantom construction, comparing their attenuation properties at two different set-ups: at a Calibration Laboratory and directly to a mammography unit. The attenuation of 3D printed test phantoms of two types of common 3D printing Fused Filament Fabrication (FFF) filaments (ABS and PLA) were characterized in comparison with polymethylmethacrylate (PMMA). The measurements were carried out with standard IEC 61267 X-rays, using RQR 2-M and RQR 4-M beam qualities at the Instruments Calibration Laboratory, and then applied to a mammography unit, with measurements with $28 \mathrm{kV}$ and $35 \mathrm{kV}$. Attenuation characteristics evaluated indicate the suitable equivalence of PLA to PMMA for 3D printing breast complex phantoms. The plastic materials used in this study suggest that the FFF technique may be suitable for mammography phantom development. 


\section{INTRODUCTION}

Mammography is the preferred technique for early detection of breast cancer. Due to the similarity in composition of the normal and abnormal tissues that comprise the breast, the optimization of image quality (IQ) and radiation doses used in mammography are crucial. Breast phantoms play an important role in the optimization process in mammography through the assessment of IQ and accurate determination of dose. They are also used in quality control (QC) and quality assurance (QA) in mammography and in optimization of specific imaging tasks, such as detection of masses and microcalcifications, dosimetry, and characterization of the imaging system performance [1-4].

The main requirement for a breast phantom is related to the composition of tissue-equivalent material, so that its attenuation properties may correspond to the human breast tissue. The most used tissue-equivalent materials are plastic (i.e., polymethyl methacrylate - PMMA) or epoxy resins [5,6], which represents breasts composed by different percentages of adipose and glandular tissues, based on breast composition presented in the literature [6-8]. Breast tissue-equivalent materials can be manufactured using components which have similar composition and densities to PMMA, utilizing novel technologies.

The considerable growth of 3D printing has stimulated the creation of a variety of radiology related objects, especially for IQ and dosimetry purposes. Currently, various 3D printing technologies are available, and the most commonly used is the Fused Filament Fabrication (FFF), also called Fused Deposition Modeling (FDM) [9]. This well-known technology is based on the thermoplastic extrusion, in which the melted plastic material is deposited layer by layer on the bed platform [10,11]. 3D printing has provided many research opportunities related to the development of radiographic QC devices [10-13] (e.g., radiochromic filmstrip holder set tools, X-ray beam alignment and collimation tools), phantoms for positron emission tomography [14,15], single photon emission tomography imaging [16] and radiotherapy [17]. In addition, the diverse infill percentages are known to change the behavior of 3D printed materials for X-ray attenuation [18$20]$.

In mammography, there is a challenge to find printing materials to simulate breast tissues, and to develop 3D printed phantoms for this application. It has been shown that a combination of 
stereolithography (SLA) and FFF materials may reach absorption proprieties close to glandular and adipose tissue at $45 \mathrm{keV}$ energy [20]. For example, Kiarashi et al. [21] have created a realistic breast phantom model using additive manufacturing technology. However, it is considered hard to incorporate pathological features within the phantom. Studies related to materials that have similar $\mathrm{X}$-ray attenuation for mammography energy range, considering diverse 3D printer set ups, are still ongoing [20,22]. However, there is a lack of papers analyzing FFF printing materials for mammography imaging and dosimetry phantoms design.

Thus, this paper reports the attenuation behavior of two common FFF printing materials acrylonitrile butadiene styrene (ABS) and polylactic acid (PLA), along with polymethylmethacrylate (PMMA) for mammography photon beams. Measurements were performed with standard X-ray beams at the Instruments Calibration Laboratory (LCI) at Instituto de Pesquisas Energéricas e Nucleares (IPEN/USP) on a mammography unit, with $28 \mathrm{kV}$ and $35 \mathrm{kV}$ beams. Experimental attenuation results were compared with reference data aiming to verify the feasibility of using commercial PLA and ABS FFF 3D printing materials to design tissue-equivalent phantoms for mammography applications.

\section{MATERIALS AND METHODS}

\subsection{D printing materials}

The ABS is synthesized from three chemical compounds: acrylonitrile, butadiene and styrene. Its three basic atomic components are Carbon, Nitrogen and Hydrogen, with Carbon being the predominant atomic species [23]. It is the most widely used thermoplastic for FFF additive manufacturing. According to Stratasys TM, developer of FFF 3D printing technology, it has been used since the development of the technique and is the most consumed material for 3D printing in the USA [24].

Poli (lactic acid), or polylactic acid (PLA) is a biodegradable thermoplastic polyester produced by condensation polymerization of lactic acid, which is derived by fermenting sugars from carbohydrate sources such as corn and sugar cane [25]. PLA stands out for its wide use in biomedical applications, due to its biocompatibility with human tissue, such as medical implants 
and surgical sutures [26]. Due to these characteristics, both ABS and PLA were chosen to be used in this study. Table 1 shows the technical and printing characteristics of these materials.

Table 1: Details on 3D printing filaments used

\begin{tabular}{ccccccc}
\hline Material & Color & $\begin{array}{c}\text { Nominal } \\
\text { Density } \\
\left(\mathbf{g} / \mathbf{c m}^{\mathbf{3}}\right)\end{array}$ & $\begin{array}{c}\text { Measured } \\
\text { Density } \\
\left(\mathbf{g . c m}^{-\mathbf{3}}\right)[\mathbf{1 9}]\end{array}$ & $\begin{array}{c}\text { Nozzle } \\
\text { Temperature } \\
\left(\mathbf{(}^{\mathbf{C}} \mathbf{C}\right)\end{array}$ & $\begin{array}{c}\text { Heated Bed } \\
\text { Temperature } \\
\left({ }^{\mathbf{0}} \mathbf{C}\right)\end{array}$ & $\begin{array}{c}\text { Print } \\
\text { Speed } \\
(\mathbf{m m} / \mathbf{s})\end{array}$ \\
\hline PLA & White & 1.24 & $1.2238(3)$ & $210-220$ & 60 & 50 \\
ABS & Orange & 1.05 & $0.9108(5)$ & $240-250$ & 105 & 50 \\
\hline
\end{tabular}

\subsection{D printed slab design}

To perform the experimental measurements of this study, PLA and ABS slabs were designed and printed using the same geometry of PMMA slabs (Figure 1). PMMA was used as a reference material because it is the standard material to simulate tissue in diagnostic imaging applications and mammography QC. Digital 3D models with dimensions of $4 \mathrm{~cm} \times 6 \mathrm{~cm}$ and thickness varying from $0.5 \mathrm{~cm}$ to $2.5 \mathrm{~cm}$ (in $0.5 \mathrm{~cm}$ increments), were created using FreeCAD software (http://www.freecadweb.org/) and saved as ".STL" format. In sequence, each model was converted to ".gcode" file using Simplify $3 \mathrm{D} \AA$ slicer software, adopting $100 \%$ rectilinear infill $\left(-45^{\circ} /+45^{\circ}\right.$ orientation) printing configuration. Each ".gcode" file was printed with ABS and PLA filaments using a FFF Core H4 3D printer (GTMax 3D®, Americana, Brazil).

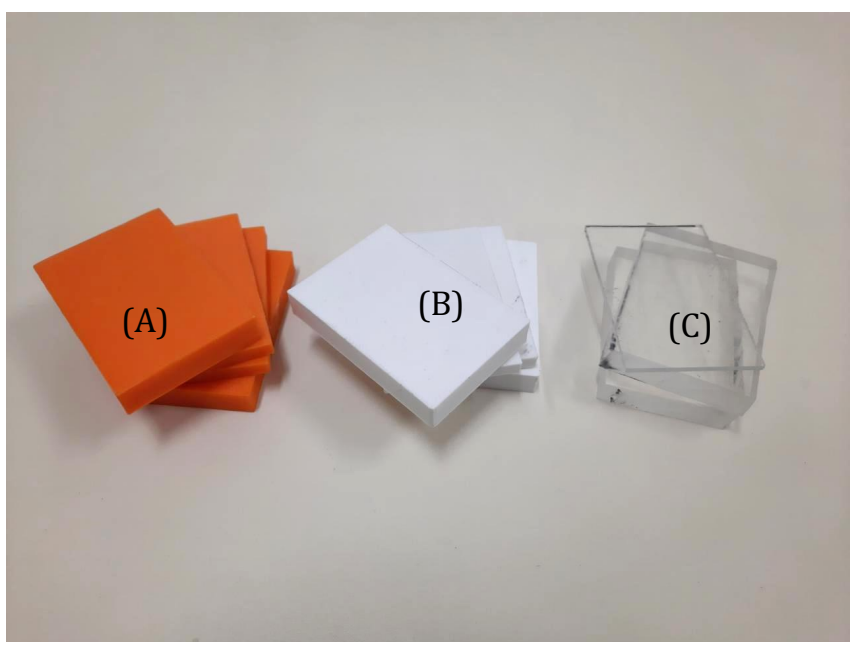

Figure 1: Materials used: a) ABS, b) PLA and c) polymethylmethacrylate (PMMA). Both, A and B were $3 \mathrm{D}$ printed. 


\subsection{Attenuation measurements using standard X-rays}

The transmission method can be used for experimental determination of the linear attenuation coefficients $\mu(E)$ of the materials. A simple exponential attenuation should be expected as a result of the impact of the beam on a detector after passing through attenuating materials of varying thickness and can be demonstrated by Equation 1:

$$
N_{x}(E)=N_{0}(E) e^{-\mu(E) x}
$$

where $N_{0}(E)$ and $N_{x}(E)$ are respectively the incident and transmitted number of photons of energy $(E)$ when passing through an attenuator of thickness $x$ [27]. To be able to compare the experimental attenuation behavior of $3 \mathrm{D}$ printed materials with reference data, the total mass attenuation coefficient $\left(\mu_{m}\right)$ needs to be calculated with Equation 2.

$$
\mu_{m}=\frac{\mu(E)}{\rho}
$$

where $\rho$ is the measured mass density of the attenuating materials used. Measurements of this study were carried out at the LCI/IPEN using standard x-ray mammography quality beans [28] to determine the attenuation coefficients of the 3D printing materials and PMMA. PLA, ABS and PMMA slabs were positioned in front of the beam exit, at $100 \mathrm{~cm}$ distance from Radcal ${ }^{\circledR}$ (California, USA) Accu-Gold+ detection system, with 10X6-6M mammography ion chamber connected. Details on experimental set-up of irradiations and beam characteristics one can find in Table 2 and Figure 2. 


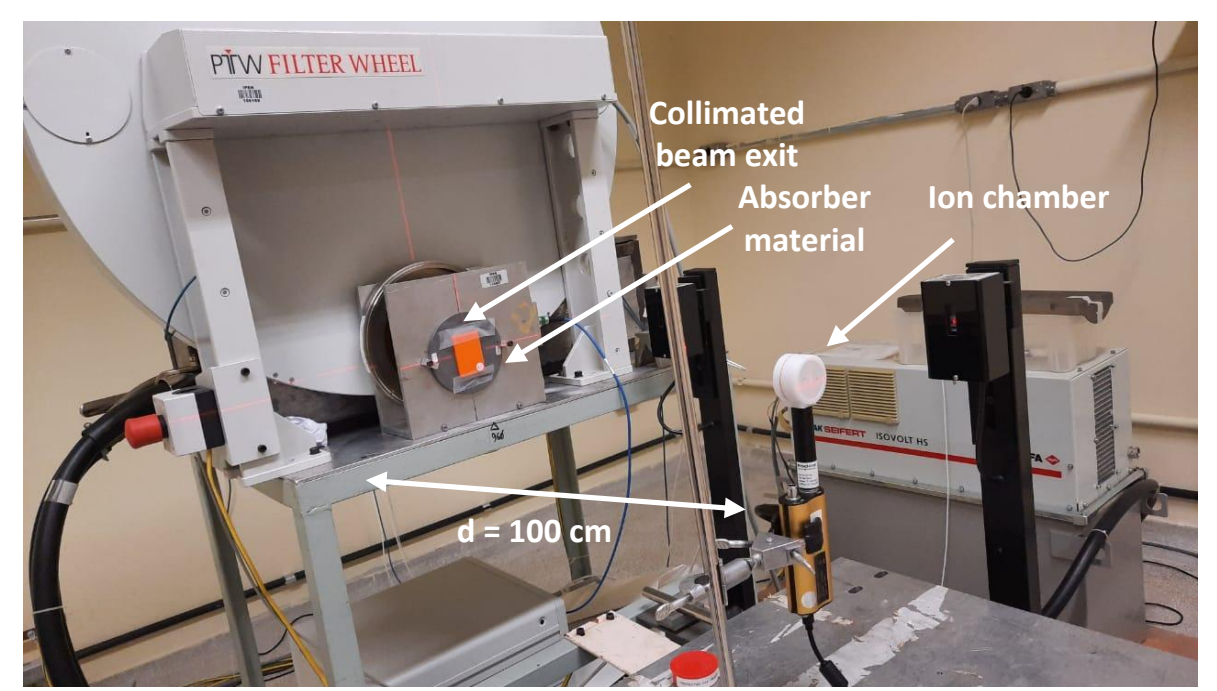

Figure 2: Irradiation set-up using Pantak/Seifert ISOVOLT 160 (GmbH \& Co. KG, Germany)

Table 2: Pantak Seifert standard beam qualities used in this work

\begin{tabular}{ccccc}
\hline Beam Quality & $\begin{array}{c}\text { Tube } \\
\text { voltage (kV) }\end{array}$ & $\begin{array}{c}\text { HVL } \\
\text { (mmAl) }\end{array}$ & $\begin{array}{c}\text { Additional Filtration } \\
\text { (mmMo) }\end{array}$ & $\begin{array}{c}\text { Mean photon energy } \\
\text { (keV) }\end{array}$ \\
\hline RQR 2-M & 28 & 0.32 & 0.03 & 15.4 \\
RQR 4-M & 35 & 0.37 & 0.03 & 16.3 \\
\hline
\end{tabular}

\subsection{Attenuation measurements using a mammography unit}

The attenuation measurements were also performed using a Konica Minolta (Tokyo, Japan) mammography unit, model Delicata 10, with Molybdenum-Molybdenum target/filter from the LABPROSAUD of Federal Institute of Bahia (Bahia, Brazil). The samples were irradiated using Manual Exposure Control with tube voltages of $28 \mathrm{kV}$ and $35 \mathrm{kV}$, and fixed current-time product (mAs) of 100 mAs. Beam detection was carried out using a calibrated multi sensor RADCAL® AccuGold with AGMSM+ MAM sensor. A support made of PLA was used for stacking of slabs above the X-ray detector at $60 \mathrm{~cm}$ from the X-ray focal spot (Figure 3). 


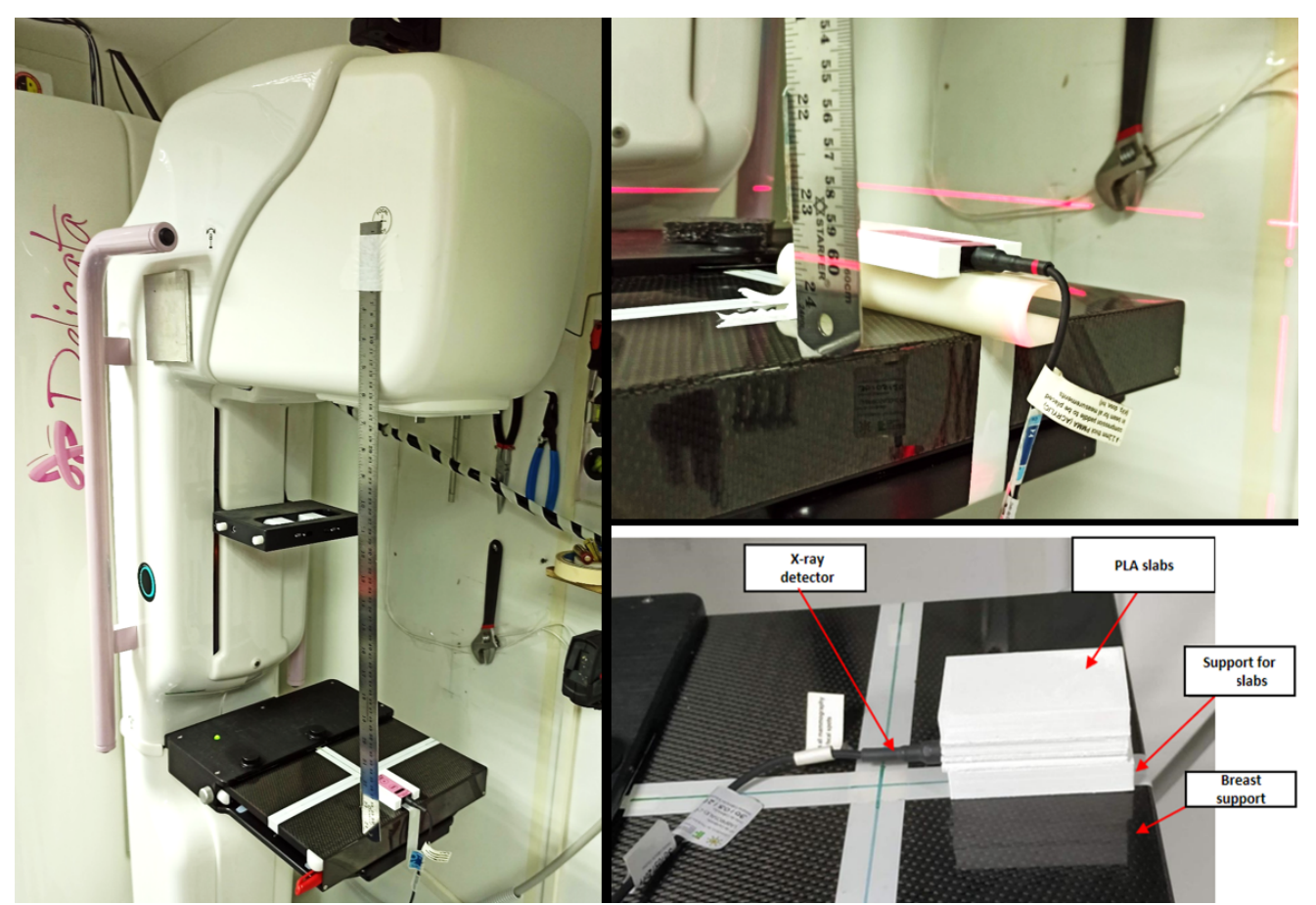

Figure 3: Mammography unit experimental set-up. Note that the breast compression paddle was not used in this attenuation investigation.

\subsection{Data analysis and reference data}

The experimental results of the approximate attenuation of the materials obtained in both irradiation arrangements are comparable to each other. As mentioned previously, we used PMMA as a reference material to compare 3D printed parts as this is the standard material to simulate tissue in diagnostic applications and mammography and quality control. The results can as well be analyzed together with reference data from NIST for breast tissue, skeletal muscle, soft tissue components of the human body of most interest when building a mammography phantom - and PMMA. The composition of the mixtures (Table 3) to calculate the reference photon cross section were obtained from National Institute of Standards and Technology (NIST) Reference Database [29] and International Commission on Radiation Units and Measurements (ICRU) 44 [6]. 
Table 3: Material constants and composition assumed for compounds and mixtures [6,29]

\begin{tabular}{|c|c|c|c|c|c|c|c|c|c|}
\hline Material & $\begin{array}{l}\text { Density } \\
\left(\text { g.cm }^{-3}\right)\end{array}$ & Component & $\mathbf{Z}$ & $\begin{array}{c}\text { Fraction by } \\
\text { weight }\end{array}$ & Material & $\begin{array}{l}\text { Density } \\
\left({\left.\mathrm{g} . \mathrm{cm}^{-3}\right)}^{-}\right.\end{array}$ & Component & $\mathbf{Z}$ & $\begin{array}{c}\text { Fraction by } \\
\text { weight }\end{array}$ \\
\hline \multirow{4}{*}{ ABS } & \multirow{4}{*}{1.2238} & $\mathrm{H}$ & 1 & 0.081089 & \multirow{10}{*}{ Soft Tissue } & \multirow{10}{*}{1.060} & $\mathrm{H}$ & 1 & 0.102000 \\
\hline & & $\mathrm{C}$ & 6 & 0.852623 & & & $\mathrm{C}$ & 6 & 0.143000 \\
\hline & & $\mathrm{N}$ & 7 & 0.066288 & & & $\mathrm{~N}$ & 7 & 0.034000 \\
\hline & & & & & & & $\mathrm{O}$ & 8 & 0.708000 \\
\hline \multirow{6}{*}{$\begin{array}{c}\text { Adipose } \\
\text { Tissue }\end{array}$} & \multirow{6}{*}{1,127} & $\mathrm{H}$ & 1 & 0.101330 & & & $\mathrm{Na}$ & 11 & 0.002000 \\
\hline & & $\mathrm{C}$ & 6 & 0.775498 & & & $\mathrm{P}$ & 15 & 0.003000 \\
\hline & & $\mathrm{N}$ & 7 & 0.035057 & & & $\mathrm{~S}$ & 16 & 0.003000 \\
\hline & & $\mathrm{O}$ & 8 & 0.052315 & & & $\mathrm{Cl}$ & 17 & 0.002000 \\
\hline & & $\mathrm{F}$ & 9 & 0.017423 & & & $\mathrm{~K}$ & 19 & 0.003000 \\
\hline & & $\mathrm{Ca}$ & 20 & 0.018377 & & & & & \\
\hline \multirow{9}{*}{$\begin{array}{l}\text { Breast } \\
\text { Tissue }\end{array}$} & \multirow{9}{*}{1.020} & & & & \multirow{4}{*}{ PLA } & \multirow{4}{*}{0.9108} & $\mathrm{H}$ & 1 & 0.055946 \\
\hline & & $\mathrm{H}$ & 1 & 0.106000 & & & $\mathrm{C}$ & 6 & 0.500012 \\
\hline & & $\mathrm{C}$ & 6 & 0.332000 & & & $\mathrm{O}$ & 8 & 0.444042 \\
\hline & & $\mathrm{N}$ & 7 & 0.030000 & & & & & \\
\hline & & $\mathrm{O}$ & 8 & 0.527000 & \multirow{5}{*}{ PMMA } & \multirow{5}{*}{1.190} & $\mathrm{H}$ & 1 & 0.080541 \\
\hline & & $\mathrm{Na}$ & 11 & 0.001000 & & & $\mathrm{C}$ & 6 & 0.599846 \\
\hline & & $\mathrm{Mg}$ & 12 & 0.001000 & & & $\mathrm{O}$ & 8 & 0.319613 \\
\hline & & $\mathrm{P}$ & 15 & 0.002000 & & & & & \\
\hline & & $\mathrm{Cl}$ & 17 & 0.001000 & & & & & \\
\hline \multirow{9}{*}{ Muscle } & \multirow{9}{*}{1.050} & $\mathrm{H}$ & 1 & 0.102000 & & & & & \\
\hline & & $\mathrm{C}$ & 6 & 0.143000 & & & & & \\
\hline & & $\mathrm{N}$ & 7 & 0.034000 & & & & & \\
\hline & & $\mathrm{O}$ & 8 & 0.710000 & & & & & \\
\hline & & $\mathrm{Na}$ & 11 & 0.001000 & & & & & \\
\hline & & $\mathrm{P}$ & 15 & 0.002000 & & & & & \\
\hline & & $\mathrm{S}$ & 16 & 0.003000 & & & & & \\
\hline & & $\mathrm{Cl}$ & 17 & 0.001000 & & & & & \\
\hline & & $\mathrm{K}$ & 19 & 0.004000 & & & & & \\
\hline
\end{tabular}

\section{RESULTS AND DISCUSSION}

\subsection{Linear attenuation coefficients $(\mu(E))$}

Figures 4 and 5 show the experimental results on radiation transmission of PLA, ABS and PMMA slabs for a standard x-ray beam and using the mammography unit, respectively. Using Equation 1 and calculating an exponential fit through the data points, the linear attenuation coefficients were obtained (Table 4). To all the presented results, the error bars (visible when bigger than the data points) represents the standard uncertainty of the measurement at $1-\sigma$ level of confidence. The fitted functions to all the presented data obtained $R^{2}$ values $\geq 0.99$. 

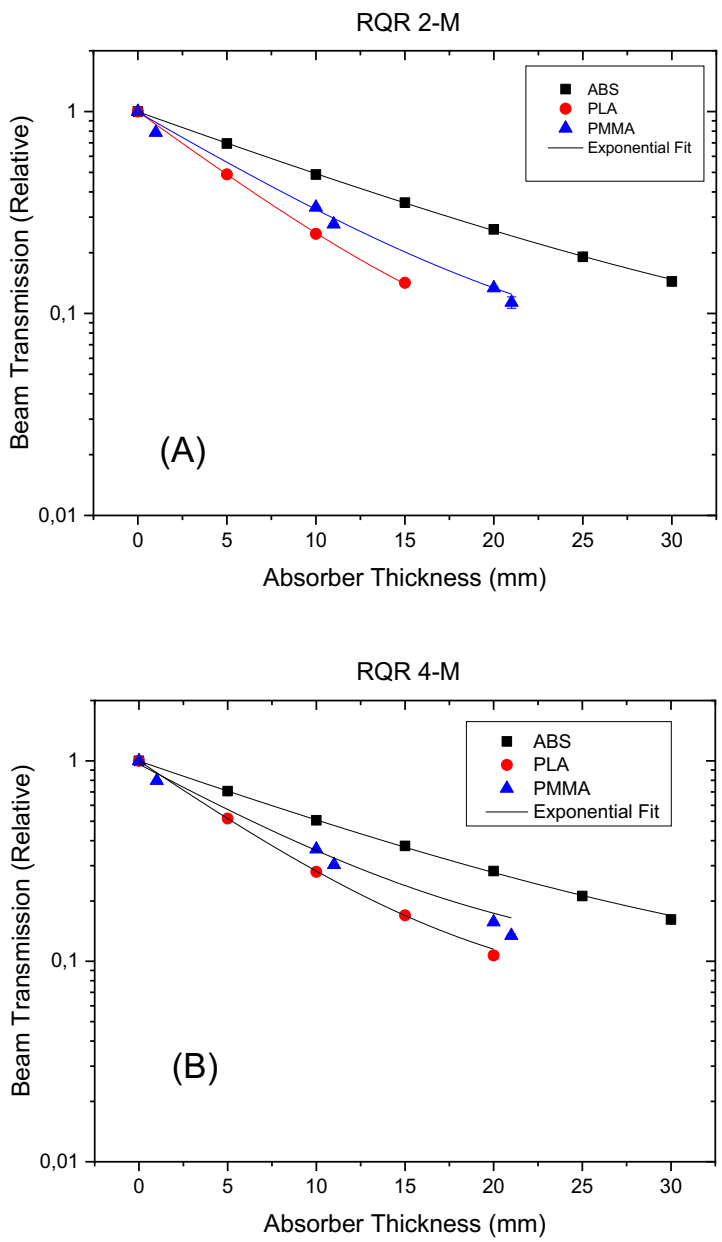

Figure 4: Pantak Seifert beam transmission with ABS, PLA and PMMA slabs for (a) RQR 2-M and (b) RQR 4-M 

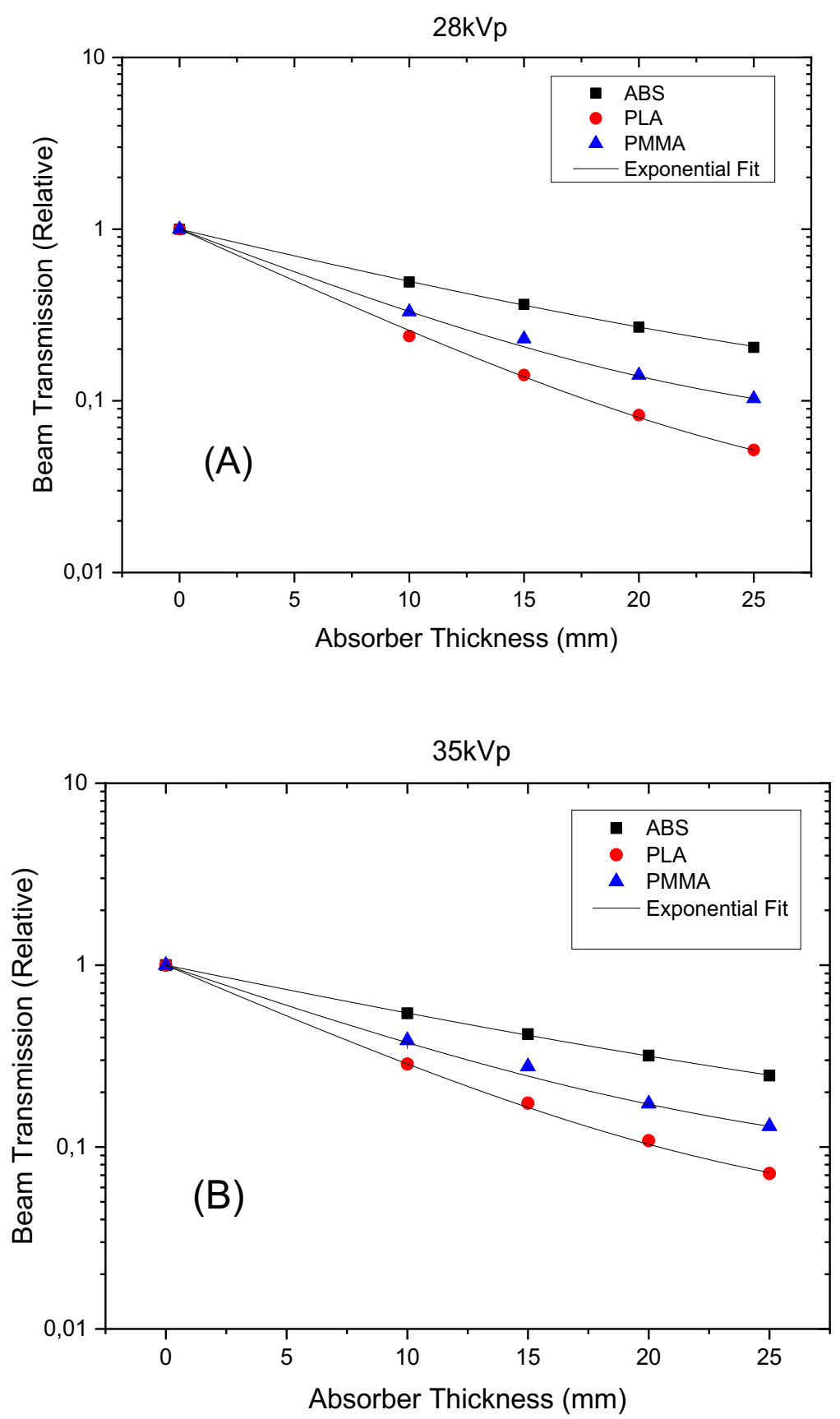

Figure 5: Mammography beam transmission with ABS, PLA and PMMA slabs for (a) $28 \mathrm{kV}$ and (b) $35 \mathrm{kV}$ 
Table 4: Experimental linear attenuation coefficients obtained with Pantak Seifert and mammography unit measurements

\begin{tabular}{|c|c|c|}
\hline & $\begin{array}{l}\text { RQR 2-M } \\
\mu\left(\mathrm{mm}^{-1}\right)\end{array}$ & $\begin{array}{c}28 \mathrm{kV}^{*} \\
\mu\left(\mathrm{mm}^{-1}\right)\end{array}$ \\
\hline ABS & $0.076(1)$ & $0.079(3)$ \\
\hline PLA & $0.153(2)$ & $0.143(3)$ \\
\hline \multirow[t]{2}{*}{ PMMA } & $0.124(24)$ & $0.125(4)$ \\
\hline & $\begin{array}{c}\text { RQR 4-M } \\
\mu\left(\mathrm{mm}^{-1}\right)\end{array}$ & $\begin{array}{c}35 \mathrm{kV}^{* * *} \\
\mu\left(\mathrm{mm}^{-1}\right)\end{array}$ \\
\hline ABS & $0.076(2)$ & $0.068(2)$ \\
\hline PLA & $0.146(1)$ & $0.152(3)$ \\
\hline PMMA & $0.120(39)$ & $0.113(4)$ \\
\hline
\end{tabular}

* $\mathrm{kV}$ measured of $26.6 \mathrm{kV}$

** $\mathrm{kV}$ measured of $32.4 \mathrm{kV}$

\subsection{Total mass attenuation $\left(\boldsymbol{\mu}_{\boldsymbol{m}}\right)$}

The experimental results for the approximated total mass attenuation coefficients $\left(\mu_{m}\right)$ obtained for ABS, PLA and PMMA are presented in Table 5. Using PMMA experimental results as a reference, Table 6 show the ratio between PMMA, ABS and PLA's total mass attenuation coefficients. The presented uncertainties were obtained by the error propagation of the components of the measurements at $1-\sigma$ confidence level.

Table 5: Total mass attenuation coefficients

\begin{tabular}{cccc}
\hline $\begin{array}{c}\text { Beam } \\
\text { Quality }\end{array}$ & $\begin{array}{c}\text { ABS } \\
\mathbf{c m}^{2} / \mathbf{g}\end{array}$ & $\begin{array}{c}\text { PLA } \\
\mathbf{c m}^{2} / \mathbf{g}\end{array}$ & $\begin{array}{c}\text { PMMA } \\
\mathbf{c m}^{2} / \mathbf{g}\end{array}$ \\
\hline RQR2-M & $0.84(2)$ & $1.25(2)$ & $1.04(2)$ \\
RQR4-M & $0.83(2)$ & $1.19(1)$ & $1.01(3)$ \\
$\mathbf{2 8 k V}$ & $0.87(3)$ & $1.25(4)$ & $1.05(3)$ \\
$\mathbf{3 5 k V}$ & $0.75(3)$ & $1.17(3)$ & $0.95(3)$ \\
\hline
\end{tabular}

Table 6: Ratio between PMMA and 3D printing filaments total mass attenuation coefficients

\begin{tabular}{cc}
\hline $\mathbf{R}_{\text {(ABS) }}$ & $\mathbf{R}_{\text {(PMMA) }}$ \\
(ABS/PMMA) & (PLA/PMMA) \\
\hline $0.804(17)$ & $1.203(19)$ \\
$0.823(27)$ & $1.181(12)$ \\
$0.827(37)$ & $1.185(30)$ \\
$0.789(30)$ & $1.234(29)$ \\
\hline
\end{tabular}




\subsection{Comparison with reference data}

The experimental results obtained for PMMA, PLA and ABS can be compared with reference data available at NIST database in terms of total mass attenuation. The coefficients were calculated using Equation 2 and compared with reference cross section of Muscle, PMMA, Soft Tissue, Breast Tissue, Breast Adipose Tissue and Breast Glandular Tissue [7]. These results are presented in Figure 6.

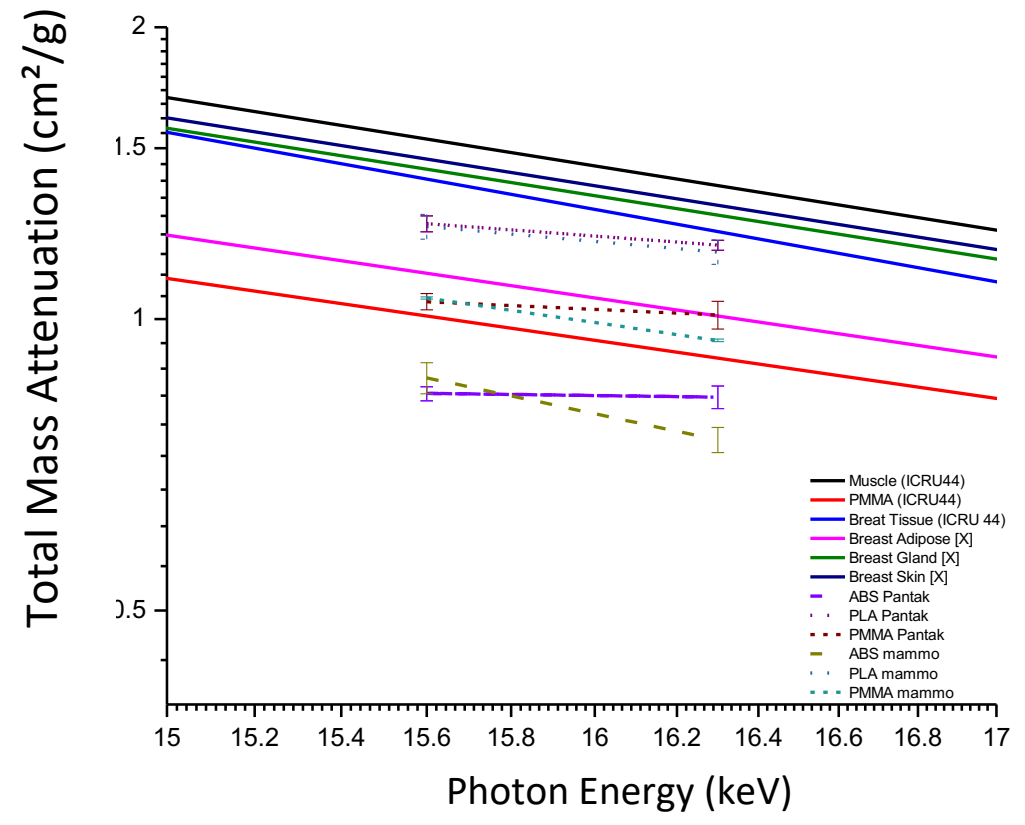

Figure 6: Experimental total mass attenuation of PMMA, PLA and ABS for both standard X-rays and mammography unit measurements compared with reference data. The $x$ axis the energy values are the mean beam energies presented in Table 2

Both conditions of measurement presented an exponential behavior of beam transmission. The results show agreement between values from the mammography unit measurements compared to standard quality beams (Figures 4 and 5). As expected, the values of attenuation coefficients decrease with the increase of the energy of photons. 
The results on Table 3 show slight discrepancy between the RQR 2-M and mammography unit $28 \mathrm{kV}$ measurements for PLA measurements. Similar results with RQR4-M and $35 \mathrm{kV}$ for ABS were obtained. These variations may have happened due to the characteristics of the printed parts that, even configured to be $100 \%$ filled with PLA or ABS, present a small internal air web due to the intrinsic characteristics of $3 \mathrm{D}$ printing by FFF [16,30], that may contribute to differences in absorption and scattering of the radiation. PMMA measurements with both set ups presented statistically equivalent behavior within $1-\sigma$.

The total mass attenuation behavior of PMMA plates almost matched PMMA reference data, and this validates the measurement process adopted in the study. Figure 6 shows that PLA attenuation ranged between reference PMMA, Soft and Breast Tissues while ABS presented the lowest attenuation properties among the studied materials. Our findings on the attenuation values demonstrate that a mammography unit can be used as way of attenuation coefficient determination in the absence of standard quality beams if it is calibrated. This opens a range of opportunities to our research group to perform measurements with other 3D printing materials previously studied in diagnostic $\mathrm{x}$-ray energy range [16].

Among the materials studied, PLA is closer to the reference attenuation of breast tissues, even more so than the PMMA itself used as a standard reference in mammography measurements. When compared with the values for specific breast tissues documented by Hammerstein et al. [7] (Figure 6), PLA stays relatively distant from Breast Gland and Breast Skin.

Studies in the literature show the possibility of developing complex and realistic breast simulators using advanced 3D printing techniques [20,31]. However, finding materials capable of being used for this purpose using the FFF 3D printing technique is still a challenge. The results found in this study corroborate with Feradov et al. [32] and their results on PLA suitability for skin tissue equivalence. 


\section{CONCLUSIONS}

This paper reports the behavior of two commercial FFF 3D printing materials on standard mammography beams. PMMA measurements were also performed as a reference and all results compared with reference data. Attenuation characteristics evaluated indicate the suitability of PLA to PMMA for 3D printing breast complex phantoms. The plastic materials used in this study associated with FFF 3D printing technique may be suitable for mammography phantom development. In terms of tissue-equivalent materials for representation of breast structures such as pathologic tissue or glandular tissue, more technical aspects should be evaluated.

The applied methodology for determining the attenuation of the materials proved to be effective in both experimental arrangements used. Therefore, a mammography unit can be used as way of attenuation coefficient determination in the absence of standard quality beams if it is calibrated.

\section{ACKNOWLEDGMENT}

The authors would like to thank the Federal Institute of Bahia, Brazil, GTecRAD (Grupo de Pesquisa em Tecnologia em Radiologia), LABIMM and LABPROSAUD, for their help in conducting this study; and Conselho Nacional de Desenvolvimento Científico e Tecnológico CNPq (process number 142098/2017-5) for the financial support.

\section{REFERENCES}

[1] ACR. Mammography quality control manual. Reston: American College of Radiology 1999.

[2] DEWERD, L. A., WOCHOS, J., \& CAMERON, J. ACR phantom based upon a random phantom “Wisconsin mammography phantoms". In W. Logan \& E. P. Muntz (Eds.), Reduced dose mammography. New York: Masson. 1979

[3] POLETTI, M. E., GONÇALVES, O. D., \& MAZZARO, I. X-ray scattering from human breast tissues and breast-equivalent materials. Phys Med Biol,v. 47, p. 47-63. 2002

[4] DEWERD, LARRY A. The phantoms of medical and health physics. Ed. Michael Kissick. Berlin: Springer, 2014. 
[5] WHITE, D. R. Formulation of tissue substitute materials using basic interaction data. Phys Med Biol, v. 22, p.889-899, 1977.

[6] WHITE, D. R., R. V. GRIFFITH, AND I. J. WILSON. ICRU reports." Reports of the International Commission on Radiation Units and Measurements v.1, p. 203-205, 1992.

[7] HAMMERStein, G. R., Miller, D. W., White, D. R., MASTERSON, M. E., WOODARD, H. Q., \& LAUGHLIN, J. S. Absorbed radiation-dose in mammography. Radiology, v.130,p. 485-491, 1979.

[8] WOODARD, H. Q., \& WHITE, D. R. The composition of body-tissues. Br. J. Radiol., v.59, p.1209-1219, 1986.

[9] SCULPTEO. The state of 3D printing. Ed 2018 2018:1-30. Available at: https://info.sculpteo.com/the-state-of-3d-printing-2018. Last accessed: 04 Aug. 2021

[10] PAXTON N, SMOLAN W, BÖCK T, MELCHELS F, GROLL J, JUNGST T. Proposal to assess printability of bioinks for extrusion-based bioprinting and evaluation of rheological properties governing bioprintability. Biofabrication $\quad$ v. $\quad 9$, p. 044107,2017 https://doi.org/10.1088/1758-5090/aa8dd8.

[11] OZBOLAT IT, HOSPODIUK M. Current advances and future perspectives in extrusion$\begin{array}{lllll}\text { based bioprinting. } & \text { Biomaterials, } & \text { v. } & 76, & \text { p.321-43, }\end{array}$ https://doi.org/10.1016/j.biomaterials.2015.10.076.

[12] OGDEN KM, MORABITO KE, DEPEW PK. 3D printed testing aids for radiographic $\begin{array}{llllllll}\text { quality control. J Appl Clin Med Phys v.20, } & \text { p.127-34, } 2019\end{array}$ https://doi.org/10.1002/acm2.12574.

[13] OLIVEIRA M, BARROS JC, UBEDA C. Development of a 3D printed quality control tool for evaluation of x-ray beam alignment and collimation. Phys Medica. v.65, p.29-32, 2019 https://doi.org/10.1016/j.ejmp.2019.07.026.

[14] MILLER MA, HUTCHINS GD. Development of anatomically realistic PET and PET/CT phantoms with rapid prototyping technology. IEEE Nucl Sci Symp Conf Rec,v.6, p. 4252-7, 2007. https://doi.org/10.1109/NSSMIC.2007.4437056.

[15] BIENIOSEK MF, LEE BJ, LEVIN CS. Technical Note: Characterization of custom 3D printed multimodality imaging phantoms. Med Phys v. 42, p.5913-8, 2015 https://doi.org/10.1118/1.4930803. 
[16] HUNT DC, EASTON H, CALDWELL CB. Design and construction of a quality control phantom for SPECT and PET imaging. Med Phys, v.36,p. 5404-11, 2009 https://doi.org/10.1118/1.3250855.

[17] KIM MJ, LEE SR, LEE MY, SOHN JW, YUN HG, CHOI JY, et al. Characterization of 3D printing techniques: Toward patient specific quality assurance spine-shaped phantom for stereotactic body radiation therapy. PLoS One, v.12, p.1-12, 2017 https://doi.org/10.1371/journal.pone.0176227.

[18] VILLANI, D., O. RODRIGUES JR, AND L. L. CAMPOS. Dosimetric characterization of 3D printed phantoms at different infill percentages for diagnostic X-ray energy range. Radiat Phys Chem, v. 172,p. 108728, 2020.

[19] SAVI M, ANDRADE MAB, POTIENS MPA. Commercial filament testing for use in 3D printed phantoms. Radiat Phys Chem. v.107, p.108906, 2020 https://doi.org/10.1016/J.RADPHYSCHEM.2020.108906.

[20] IVANOV D, BLIZNAKOVA K, BULIEV I, POPOV P, METTIVIER G, RUSSO P, et al. Suitability of low density materials for 3D printing of physical breast phantoms. Phys Med Biol 2018;63:175020. https://doi.org/10.1088/1361-6560/aad315.

[21] KIARASHI N, RAVIN CE, NOLTE AC, STURGEON GM, SEGARS WP, NOLTE LW, et al. Development of realistic physical breast phantoms matched to virtual breast phantoms based on human subject data; Development of realistic physical breast phantoms matched to virtual breast phantoms based on human subject data. Med Phys v.42, p. 4116, 2015 https://doi.org/10.1118/1.4919771.

[22] MAINPRIZE J, CARTON A-K, KLAUSZ R, LI Z, MULLER SL, HUNTER DM, et al. Development of a physical 3D anthropomorphic breast texture model using selective laser sintering rapid prototype printing. In: Chen G-H, Lo JY, Gilat Schmidt T, editors. Med. Imaging 2018 Phys. Med. Imaging, SPIE; 2018, p. 9. https://doi.org/10.1117/12.2293560.

[23] RUTKOWSKI, J. V.; LEVIN, C. B. Acrylonitrile-Butadiene-Styrene Copolymers (ABS): Pyrolysis and Combustion Products and their Toxicity - A review of the Literature. Fire and Materials, v.10, p.93-105, 1986.

[24] FRED FISCHER. Themoplastics: The Best Choice for 3D Printing: Why ABS is a Good Choice for 3D Printing and When to use Another Thermoplastic. Available at: 
https://www.smg3d.co.uk/files/ssys-wp-thermoplastics-09-11_ashx.pdf Last accessed: 04 Aug. 2021.

[25] CASTRO-AGUIRRE, E.; IÑIGUEZ-FRANCO, F.; SAMSUDIN, H.; FANG, X.; AURAS, R. Poly(lactic acid)-Mass production, processing, industrial applications, and end of life. Advanced Drug Delivery Reviews, v. 107, p. 333-366, 2016. doi:10.1016/j.addr.2016.03.010.

[26] GIAMMONA, G. and CRAPARO, E. F. "Biomedical applications of polylactide (PLA) and its copolymers." Molecules v.4, p. 980, 2018 https://doi.org/10.3390/molecules23040980.

[27] KNOLL, Glenn F. Radiation detection and measurement. John Wiley \& Sons, 2010. 4th ed.

[28] International Electrotechnical Commission (IEC). Medical diagnostic X-ray equipment Radiation conditions for use in the determination of characteristics, IEC 61267. 2005.

[29] HUBBELL, J. H., and S. M. Seltzer. X-ray mass attenuation coefficients. NIST Standard Reference Database v. 126, p. 2004,2019.

[30] TURNER, Brian N.; GOLD, Scott A. A review of melt extrusion additive manufacturing processes: II. Materials, dimensional accuracy, and surface roughness. Rapid Prototyping Journal, v. 21, p. 250-261, 2015. doi:10.1108/RPJ-02-2013-0017.

[31] MALLIORI A, DASKALAKI A, DERMITZAKIS A, PALLIKARAKIS N. Development of Physical Breast Phantoms for X-ray Imaging Employing 3D Printing Techniques. Open Med Imaging J v.12, p.1-10. 2020 https://doi.org/10.2174/1874347102012010001.

[32] FERADOV F, MARINOV S, BLIZNAKOVA K. Physical Breast Phantom Dedicated for Mammography Studies. In: Henriques J, Neves N, de Carvalho P, editors. XV Mediterr. Conf. Med. Biol. Eng. Comput. MEDICON 2019, Cham: Springer International Publishing, p. $344-$ 52, 2020. https://doi.org/10.1007/978-3-030-31635-8_41 